\title{
Studi Distribusi Glukosa Transporter 4 pada Otot Skelet Ayam Kedu Cemani
}

\section{Study of Glucose Transporter 4 Distribution in Skeletal Muscle of Kedu Cemani Chicken}

\author{
Teguh Budipitojo, Ariana, Tri Wahyu Pangestiningsih, Hery Wijayanto, \\ Dwi Liliek Kusindarta, Dewi Kania Musana \\ Departemen Anatomi, Fakultas Kedokteran Hewan, Universitas Gadjah Mada, \\ Jl. Fauna No. 2 Karangmalang, Yogyakarta, \\ Email : budipitojo@ugm.ac.id
}

\begin{abstract}
Glucose transporter (GLUT 4) is glucose transporter protein regulated by insulin, found in adipose tissue and striated muscle (skeletal and cardiac muscle). Kedu cemani chicken is one of Indonesia endemic animal, discovered in Kedu, Temanggung regency, Central Java. This study was required to complete microscopic documentation of Indonesia's native biodiversity. The objective of this study was to clarify GLUT 4 distribution in skeletal muscle fibres of kedu cemani chicken by using avidin-biotin-peroxidase complex $(A B C)$ immunohistochemistry method. This study was conducted by using pectoralis major, biceps brachii, and biceps femoris muscle tissue from 5 kedu cemani chicken. The result showed that GLUT 4 immunoreactivity was detected in sarcolemma and myofibrils component of the pectoralis major, biceps brachii, and biceps femoris muscle tissue. The intensity of GLUT 4 immunoreactivities increased from weak intensity in pectoralis major muscle tissue, moderate intensity in biceps brachii muscle tissue, then strong intensity in biceps femoris muscle tissue. This result might motivate to further exploration of the other kedu cemani chicken-specific features to complete microscopic documentation of Indonesia's native biodiversity.
\end{abstract}

Keyword : kedu chicken, skeletal muscle, GLUT4, immunohistochemistry

\begin{abstract}
Abstrak
Glucose Transporter 4 (GLUT 4) merupakan protein transporter glukosa yang diatur oleh insulin, ditemukan terutama di jaringan adiposa dan otot lurik (baik otot skelet maupun otot jantung). Ayam kedu cemani merupakan ayam endemik Indonesia yang terdapat di wilayah Kedu, Temanggung, Jawa Tengah. Penelitian ini diperlukan untuk melengkapi dokumentasi data anatomi mikroskopik kekayaan hayati asli Indonesia. Penelitian ini bertujuan untuk mengklarifikasi distribusi GLUT 4 dalam serabut otot skelet ayam kedu dengan metode imunohistokimia avidinbiotin-peroxidase complex (ABC). Penelitian dilakukan dengan menggunakan jaringan otot yang meliputi otot pectoralis mayor, biceps brachii, dan biceps femoris dari 5 ekor ayam kedu cemani. Hasil penelitian menunjukkan bahwa immunoreaktivitas GLUT 4 terutama terdeteksi di sarkolema dan komponen miofibril pada otot pectoralis mayor, biceps brachii, maupun biceps femoris. Intensitas imunorekatifitasnya meningkat dari intensitas lemah pada otot pectoralis mayor, menjadi intensitas sedang pada otot biceps brachii, dan kemudian intensitas kuat pada otot biceps femoris. Hasil penelitian memunculkan dorongan untuk menggali lebih lanjut ciri-ciri khusus ayam kedu cemani lainnya, untuk mendokumentasi data anatomis kekayaan hayati asli Indonesia.
\end{abstract}

Kata kunci: ayam kedu , otot skelet, GLUT 4, immunohistokimia

\section{Pendahuluan}

Ayam kedu atau dikenal juga sebagai ayam cemani merupakan ayam endemik Indonesia yang terdapat di wilayah Kedu, Temanggung, Jawa Tengah. Ayam ini memiliki ciri khusus berupa otot yang memiliki warna hitam kelam. Telah diketahui bahwa warna hitam pada otot ayam kedu terkait dengan pigmen dominan melanin yang ada di dalamnya. Penelitian mengenai ayam kedu cemani masih sangat terbatas. Penelitian terdahulu megenai ayam kedu cemani meliputi perkembangbiakan serta studi mengenai perubahan warna bulu ayam kedu cemani anakan hingga dewasa (Merkens dan Mohede, 1941). Selain itu penelitian dari aspek sosial, oleh masyarakat 
Indonesia ayam kedu cemani dinilai memiliki kedudukan sosial karena mempunyai ciri yang spesifik. Pemanfaatan ayam kedu cemani oleh masyarakat yaitu sebagai hewan kesayangan, dikonsumsi sebagai obat yang berkhasiat sebagai penambah vitalitas dan diperlukan untuk upacara-upacara adat yang mampu memberi dukungan moral terhadap kehidupan pemiliknya (Muryanto dan Subiharta, 1989).

Glucose transporter 4 (GLUT 4) adalah protein yang pada manusia, pembentukannya dikode oleh gen GLUT 4. Glucose transporter 4 (GLUT 4) adalah transporter glukosa yang diatur oleh insulin, ditemukan terutama di jaringan adiposa dan otot lurik (baik otot skelet maupun otot jantung). Bukti pertama untuk protein transpor glukosa ditemukan oleh David James pada tahun 1988 (James dkk., 1988). Gen yang mengkode GLUT 4 dikloning (James dkk., 1989; Birnbaum, 1989) dan dipetakan pada tahun 1989 (Bell dkk., 1989). Glucose transporter 4 (GLUT 4) merupakan transporter glukosa yang penting dalam mempertahankan homeostasis glukosa dalam tubuh. Penelitian mengenai gangguan gen GLUT 4 pada tikus menunjukkan adanya penurunan GLUT 4 di jaringan, adaya resistensi insulin dan perkembangan diabetes melitus (Sherperd dan Kahn., 1999). Pada sel otot dan jaringan adiposa yang normal, dalam kondisi tidak terpengaruh insulin, GLUT 4 terdapat di intrasel. Stimulus insulin ataupun stimulus lain mentranslokasikan GLUT 4 dari vesikel penyimpanan ke membran plasma sel otot sehingga terjadi trasport glukosa ke dalam sel (Sherperd dkk., 1999; Shulman, 2000).

Otot skelet adalah otot yang berfungsi menentukan dan mengontrol pergerakan hewan, melekat pada tulang secara langsung maupun melalui tendon. Selain itu, otot skelet berfungsi untuk mempertahankan postur, mendukung dan melindungi jaringan otot lunak serta berkontribusi untuk mempertahankan suhu tubuh (Tartaglia dan Waugh,
2005). Unggas pada umumnya mempunyai otot-otot gerak yang kuat untuk terbang. Otot pectoralis mayor dan biceps brachii merupakan otot utama yang berperan untuk mengepakkan sayap dan terbang. Selain sayap, ayam merupakan unggas yang lebih sering bergerak dengan kaki. Otot biceps femoris merupakan otot yang berperan dalam pergerakan kaki. Keberadaan dan distribusi GLUT 4 pada sel otot skelet ayam kedu cemani yang sedikit gerakannya dan yang banyak kontraksinya belum diketahui. Penelitian ini bertujuan untuk mengklarifikasi distribusi imunoreaktifitas GLUT 4 dalam serabut otot skelet ayam kedu cemani dengan metode imunohistokimia avidin-biotin-peroxidase complex.

\section{Materi dan Metode Penelitian}

\section{Sampel dan Preparasi Jaringan}

Penelitian ini menggunakan 5 ekor ayam cemani jantan berumur 8 bulan yang diambil dari Desa Kedu, Kecamatan Kedu, Kabupaten Temanggung, Jawa Tengah. Hewan dikorbankan setelah lebih dulu ditidurkan dengan kloroform. Setelah dikorbankan, sampel jaringan otot yang meliputi otot pectoralis mayor, biceps brachii, dan biceps femoris kanan dan kiri dikoleksi dan difiksasi dalam larutan Bouins selama 24 jam, kemudian dipindah dalam larutan alkohol 70\%. Selanjutnya, potongan sampel diproses untuk pembuatan blok parafin dan dipotong dengan ketebalan $4 \mu \mathrm{m}$. Potongan otot membujur dan melintang pada gelas objek digunakan untuk pewarnaan imunohistokimia dengan metode AvidinBiotin-Complex (ABC) dengan antibodi primer antiGLUT 4.

\section{Pewarnaan Imunohistokimia terhadap GLUT 4 dengan Metode Avidin-Biotin-Complex (ABC)}

Deteksi GLUT 4 menggunakan antibodi primer poliklonal anti-GLUT 4 (1:100). Pewarnaan Imunohistokimia metode $\mathrm{ABC}$ diawali dengan proses 
deparafinisasi dan rehidrasi pada sampel. Selanjutnya, dilakukan antigen retrieval dengan menginkubasi sampel jaringan dalam akuades di microwave selama 10 menit. Sampel jaringan diinkubasi dalam $100 \mathrm{ml}$ methanol yang mengandung $30 \% \quad \mathrm{H}_{2} \mathrm{O}_{2}$ untuk menghambat aktivitas peroksidase endogen selama 10 menit. Setelah dicuci dengan PBS, secara berurutan sampel jaringan diinkubasi dalam serum kambing normal selama 30 menit pada suhu kamar dan selanjutnya dengan antibodi primer anti-GLUT 4 (1:100) dengan diluen bufer, selama 12 jam pada suhu $4^{\circ} \mathrm{C}$. Kontrol negatif tidak diberi antibodi primer anti GLUT 4. Setelah dicuci dengan PBS, selanjutnya sampel jaringan diinkubasi selama 30 menit dalam suhu kamar dengan antibodi sekunder anti-IgG tikus yang dibiotinilasi (1:200) (Vectastain ABC kit, Vector, Burlingame, CA). Berikutnya, setelah dicuci dengan PBS, sampel jaringan diinkubasi selama 30 menit dengan kompleks avidin-biotin-peroksidase (Vectastain $\mathrm{ABC}$ kit) yang disiapkan sesuai dengan instruksi pabrik. Setelah dicuci dengan PBS selama 15 menit, sampel jaringan direaksikan dengan 0,02 \% 3,3 - diaminobenzidinetetrachloride (DAB) yang dicampur dengan $0,06 \%$ hidrogen peroksida $\left(\mathrm{H}_{2} \mathrm{O}_{2}\right)$ selama 15 menit untuk mendeteksi reaksi imunogenik positif. Setelah dicuci dengan akuades, sampel jaringan didehidrasi dengan alkohol dengan konsentrasi bertingkat dan dijernihkan dengan silol, serta ditutup cover glass dengan balsam kanada (Merck, Darmstadt, Jerman). Hasil pewarnaan imunuhistokimia diamati menggunakan mikroskop cahaya (BX51, OLYMPUS, Tokyo, Jepang) dan diambil gambarnya menggunakan kamera optilab.

\section{Hasil dan Pembahasan}

Struktur histologi otot skelet pada ayam kedu cemani yang tidak berbeda dengan struktur histologi otot skelet pada umumnya. Serabut otot skelet ayam kedu cemani berbentuk bulat tidak beraturan dan memanjang dengan inti sel yang berjumlah banyak dan menempel ditepi serabut. Setiap sel otot tersusun dari miofibril, setiap miofibril adalah rangkaian sarkomer yang merupakan unit kontraksi. Setiap sarkomer tesusun dari miofilamen aktin (tipis) dan miofilamen miosin (tebal) yang tersusun tumpang tindih. Susunan miofilamen ini menghasilkan pola striasi dalam miofibril.

Penelitian ini telah mengklarifikasi keberadaan dan distribusi GLUT 4 pada otot skelet ayam cemani menggunakan antibodi poliklonal dengan teknik immunohistokimia ABC. Hasil penelitian menunjukkan bahwa imunoreaktifitas GLUT 4 terutama terdeteksi pada sarkolema serabut otot skelet ayam kedu cemani, dan kemudian di komponen miofibril, baik pada otot pectoralis mayor (Gambar A dan B ), biceps brachii (Gambar C dan D), maupun pada biceps femoris (Gambar E dan F). Intensitas imunorekatifitasnya (Tabel 1) lemah pada otot pectoralis mayor (Gambar A dan B ), sedang pada otot biceps brachii (Gambar C dan D), dan kuat pada otot biceps femoris (Gambar E dan F). Sebaliknya, otot skelet ayam kedu cemani tidak menunjukkan adanya imunoreaktifitas GLUT 4 pada prosedur kontrol negatif (Gambar $\mathrm{G}$ dan $\mathrm{H}$ ), baik pada serabut otot pectoralis mayor, biceps brachii, dan biceps femoris.

Tabel 1. Hasil evaluasi semi kuantitatif terhadap intensitas imunoreaktifitas GLUT 4 pada otot skelet pectoralis mayor, biceps brachii, dan biceps femoris ayam kedu cemani

\begin{tabular}{lccc}
\hline Otot skelet & Pectoralis mayor & Biceps brachii & Biceps femoris \\
\hline Intensitas GLUT & + & ++ & ++ \\
\hline
\end{tabular}

Keterangan: intensitas lemah $=+$, intensitas sedang $=++$, dan intensitas kuat $=+++$ 


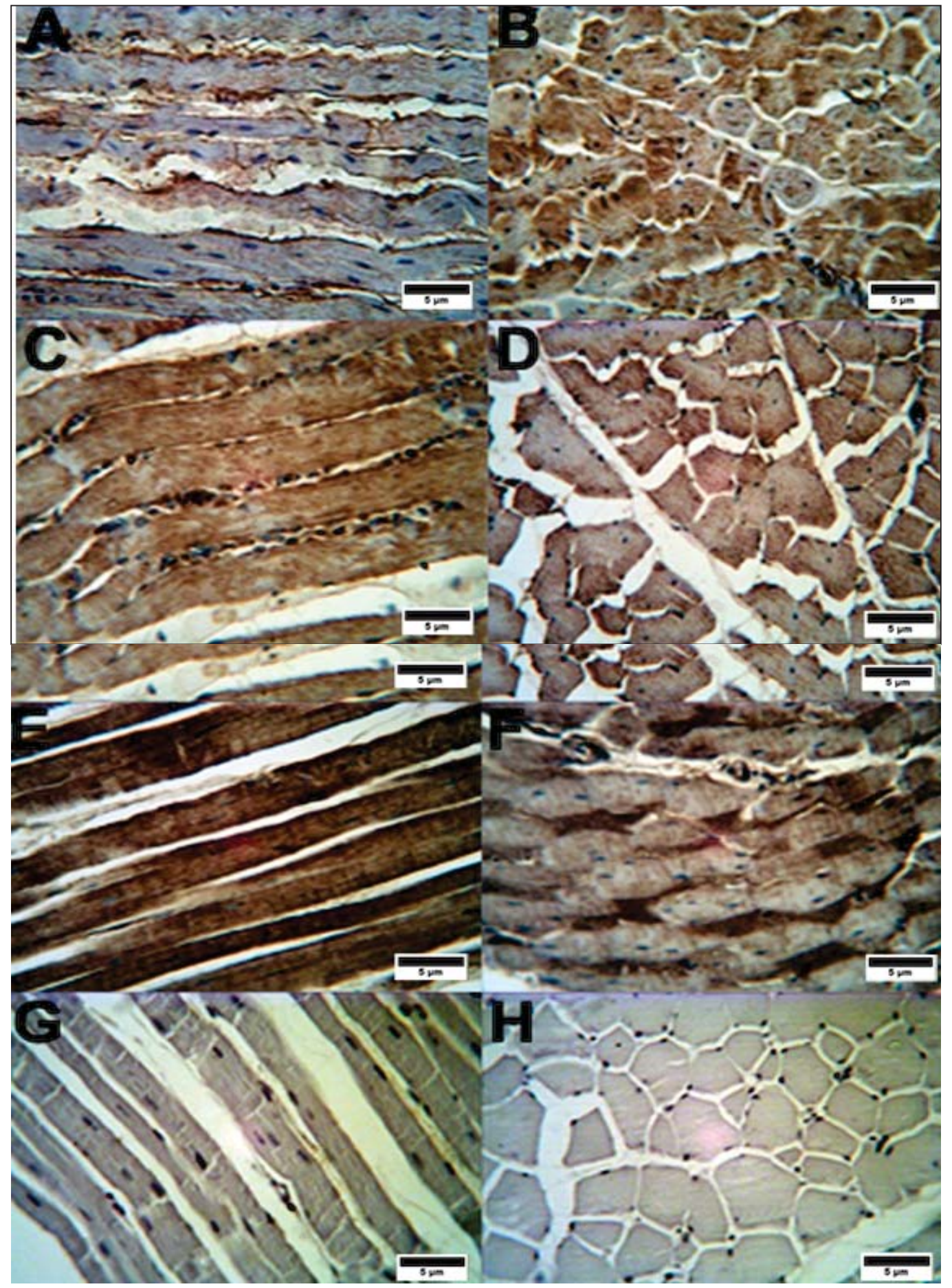

Gambar 1. Imunoreaktifitas GLUT 4 pada otot skelet ayam kedu cemani (Pewarnaan imunohistokimia ABC, 520x). Intensitas imunoreaktifitas GLUT 4 terdeteksi lemah pada otot pectoralis mayor penampang membujur (A) dan melintang (B), sedang pada otot biceps brachii penampang membujur (C) dan melintang (D), serta kuat pada otot biceps femoris penampang membujur (E) dan melintang (F). Imunoreaktifitas negatif terhadap GLUT 4 pada otot skelet ayam kedu cemani penampang membujur $(\mathrm{G})$ dan melintang $(\mathrm{H})$. 
Imunoreaktifitas GLUT 4 terdeteksi pada sarkolema dan komponen miofibril otot pectoralis mayor, biceps brachii dan biceps femoris. Sarkolema adalah memban sel serabut otot yang diaktivasi dengan adanya perubahan potensial transmembran sel sehingga menyebabkan kontraksi serabut otot. Miofilamen ini, terdiri dari 2 protein yaitu aktin dan miosin yang beperan dalam proses kontraksi. (Tartaglia dan Waugh, 2005).

Glucose transporter 4 (GLUT 4) adalah transporter glukosa yang diatur oleh insulin. Dalam kondisi rendah insulin, kebanyakan GLUT 4 disimpan dalam vesikel intraselular sel otot dan lemak. Insulin menyebabkan peningkatan secara pesat dalam penyerapan glukosa dengan cara menginduksi translokasi GLUT 4 dari vesikel ke membran plasma. Pada saat vesikel berfusi dengan membran plasma, GLUT 4 diselipkan pada membran dan siap untuk mengangkut glukosa, sehingga meningkatkan penyerapan glukosa (Cushman dan Wardzala, 1980). Pada permukaan sel, GLUT 4 memfasilitasi proses difusi pada glukosa yang beredar ke dalam sel otot dan lemak, sehingga kemudian menurunkan gradien konsentrasinya dalam darah. Setelah berada di dalam sel, glukosa dengan cepat difosforilasi oleh glukokinase di hati atau oleh heksokinase di jaringan lainnya, untuk membentuk glukosa-6-fosfat, yang kemudian memasuki glikolisis atau dipolimerisasi menjadi glikogen. Glukosa-6-fosfat tidak dapat berdifusi kembali keluar dari sel, yang juga berfungsi untuk menjaga gradien konsentrasi glukosa (Watson dkk., 2004).

Hasil penelitian menunjukkan bahwa intensitas imunoreaktifitas GLUT 4 pada otot skelet ayam kedu cemani meningkat dari intensitas lemah pada otot pectoralis mayor, menjadi sedang pada otot biceps brachii, dan kemudian kuat pada otot biceps femoris. Intensitas imunoreaktifitas GLUT 4 berkorelasi positif dengan banyaknya GLUT 4 dalam jaringan. Semakin kuat imunoreaktifitas GLUT 4 maka dapat dikatakan bahwa penggunaan glukosa oleh jaringan semakin baik, sehingga jumlah glukosa dalam darah menjadi berkurang karena diangkut ke jaringan. Di dalam jaringan, glukosa akan diubah menjadi energi yang diperoleh dari penguraian adenosin trifosfat (ATP) dan kreatin fosfat. Adenosin trifosfat (ATP) terurai menjadi adenosin difosfat (ADP) dan energi. Adenosin difosfat (ADP) terurai menjadi adenosin monofosfat (AMP) dan energi, sedangkan kreatin fosfat terurai menjadi kreatin, fosfat dan energi. Energienergi ini yang akan digunakan untuk kontraksi otot (Tartaglia dan Waugh, 2005).

Otot biceps femoris lebih banyak mengandung GLUT 4 dibanding biceps brachii dan pectoralis mayor. Hal ini menandakan aktivitas kontraksinya lebih banyak dibanding otot biceps brachii dan pectoralis mayor sehingga membutuhkan lebih banyak energi. Hal ini berkorelasi dengan tingkah laku ayam kedu cemani sebagai unggas yang lebih sering bergerak dan mencari makan dengan kaki. Otot biceps brachii dan pectoralis mayor pada ayam tidak dominan untuk terbang namun masih digunakan untuk mengepakkan sayap. Hal ini menunjukkan bahwa otot biceps femoris membutuhkan lebih banyak energi untuk bergerak sehingga mengandung GLUT 4 lebih banyak untuk mentransport glukosa ke otot sebagai sumber energi.

\section{Kesimpulan}

Imunoreaktifitas glucose transporter 4 (GLUT 4) terdeteksi dengan intensitas kuat pada otot biceps femoris, sedang pada otot biceps brachii dan lemah pada otot pectoralis mayor sebanding dengan tingginya aktivitas kontraksi dan penggunaan energi. 


\section{Daftar Pustaka}

Bell, G.I., Murray, J.C., Nakamura, Y., Kayano, T., Eddy, R.L., Fan, Y.S., Byers, M.G., and Shows, T.B. (1989) Polymorphic human insulin-responsive glucose-transporter gene on chromosome 17p13. Diabetes 38 (8): 1072-1075.

Birnbaum, M.J. (1989) Identification of a novel gene encoding an insulin-responsive glucose transporter protein. Cell 57 (2): 305-15.

Cushman, S.W, and Wardzala, L.J. (1980) Potential mechanism of insulin action on glucose transport in the isolated rat adipose cell. Apparent translocation of intracellular transport systems to the plasma membrane. $J$. Biol. Chem. 255 (10): 4758-62.

James, D.E., Brown, R., Navarro, J., and Pilch, P.F. (1988) Insulin-regulatable tissues express a unique insulin-sensitive glucose transport protein. Nature 333 (6169): 183-5.

James, D.E., Strube, M., and Mueckler, M. (1989) Molecular cloning and characterization of an insulin-regulatable glucose transporter. Nature 338 (6210) : 83-87.

Merkens, J dan J.F. Mohede. (1941) Sumbangan pengetahuan tentang ayam Kedu. Terjemahan karangan mengenai ayam Kedu dan itik di Indonesia. LIPI. Jakarta.

Muryanto dan Subiharta, (1989) Pertumbuhan dan produksi telur ayam Kedu hitam yang dipelihara secara intensif. Pros. Seminar Hasil-hasil Penelitian. Fakultas Peternakan U.G.M. Yogyokarta

Sheperd, P.R. and Kahn, B.B. (1999) Glucose Transporter and Insulin Action. N. England. J. Med. 341 (4) : 248-257.

Shulman, G. I. (2000) Cellular Mechanisms of Insulin Resistance. J. Clin. Invest. 106 (2). 106 (2 ): 171-176.

Tartaglia, L., and Waugh, A. (2005) Veterinary Physiology and Applied Anatomy. Elsevier. Toronto

Watson, R.T., Kanzaki, M., and Pessin, J.E. (2004) Regulated membrane trafficking of the insulin-responsive glucose transporter 4 in adipocytes. Endocrine Reviews 25 (2): 177-204. doi:10.1210/er.2003-0011. 